\title{
Mode of Action of a Herbicide, Benthiocarb
}

\section{Ichiro KIMURA*, Nobumasa ICHIZEN*, and Shooichi MatsunaKa**}

*Biological Laboratory, Kumiai Chemical Industry Co., Ltd., Kikugawa, Shizuoka, and

** National Institute of Agricultural Sciences, Konosu, Saitama

\section{Summary}

Mode of action of a new herbicide, benthiocarb [S-(4-chlorobenzyl) $N, N$-diethylthiolcarbamate, trade name: Saturn], was investigated. The herbicide had little effect on the Hill reaction of spinach chloroplasts, and on both photosynthesis of whole plants and respiration of excised roots in rice plant (Oryzae sativa) and barnyardgrass (Echinochloa crusgalli). Benthiocarb inhibited the $\alpha$-amylase synthesis induced by added gibberellin in rice- and barnyardgrass-endosperms, but had no effect on the hydrolysis of starch by $\alpha$-amylase preparation itself. It also inhibited the elongation of the laminaioints of excised rice leaves induced by added indoleacetic acid (IAA). In this case, benthiocarb jointly acted in an antagonic way, namely competitively, with IAA. From these results, the inhibition of protein synthesis through the competition at the auxin-acting site seemed to be one of the mode of actions of the herbicide.

\section{光 合成阻害除草剤の連合作用}

\author{
全購連農業技術センター農薬研究部 足立明朗・浜田虔二
}

\section{1. 粕 言}

近年，除草剤の急速な進歩とともにその混合剤の数は 增加の一途を辿りつつある。しかし，その混合理論はあ まり明確でなく，単に殺草草種幅を広げる狙いだけの混 合剂が主流を占め, 生理活性面からとらえた混合剤は殆 んど見られない。その原因の一つとして, 除草剤が殺虫 剂の場合の薬量 - 致死率の関係のように, 薬量一殺草程 度の関係を数量的にとらえることが難かしかったためと 考えられる。

筆者らは，除草戍の検定植物としてクロレラを検討し たところ, 殺虫剤の薬量一致死率の関倸のように, 薬量 一クロレラ増殖阻害率といら関係が得られ, 除草剤効力 の客観的な数量化が可能であること, 特に光合成阻害剤 で優れた感度を示すことを先に報告した1)。そこで, 光 合成反応に作用点を持つと思われる除草剂について，2 種類ずつ組み合わせて, その連合作用について若干の検 討を行なった。
BLISS $^{4)}$ は, 連合作用の概念を, 独立連合作用, 類似 連合作用, 協力作用の 3 作用型に類型分けしている。そ の概念は，次のようである。

独立連合作用之は, おのおのの薬剂が, 独立して作用 し異なった型の毒作用を持つ場合である。同じ光合成阻 害剤でも paraquat と DCMU ではその作用点が異な り, この両剤の混合による連合作用は独立連合作用と推 定される。類似連合作用とは, 両薬剤の連合作用が算術 和的で，両薬剤は同じ毒作用を呈し，一方の薬剤はいか なる割合の他薬剤をも評価し置き換えることができる。 光合成阻害剤のうち, dipyridinium 系の paraquat $と$ diquat, triazine 系の simetryne と prometryne, 尿素系の DCMU と linuron はそれぞれ同傾向の作用 性を有すると想定されるので，各両剤の連合作用は類似 連合作用と推定される。協力作用とは, 1 成分が他の成 分に協力するか, または拮抗する場合 (負の協力作用) を いう。ヒル反応阻害を作用性の一つとしてもつ DCPA と, 生物活性殆んどもたない 3 種の DCPA 類縁化合 
物 propionanilide, 4-chloropropionanilide, および 3,4-dichloroacetanilide とのそれぞれを組み合わせた 場合の連合作用は，協力作用にあてはまるものと考えら れる。

以上のそれぞれの 2 除草剤ずつを組み合わせて, BLIss の連合作用の 3 作用型について検討した。

\section{2. 実 験 方 法}

\section{（1）供試化合物}

供試化合物は第 1 表に示すとおりで, paraquat, diquat, simetryne, prometryne, DCMU, linuron, DCPA は,いずれも原体から再結を繰り返した精製品を用いた。

第 1 表 供 試 除 草 鼡

\begin{tabular}{|c|c|c|}
\hline 作用機構 & 除 草 鼡 & 学 \\
\hline \multirow{2}{*}{ 光要 求 性 } & paraquat & $\begin{array}{l}\text { I, l'-dimethyl-4, 4'-bipyridinium } \\
\text { dichloride }\end{array}$ \\
\hline & diquat & $\begin{array}{l}6,7 \text {-dihydrodipyrido }\left[1,2-a: 2^{\prime}, 1^{\prime}-\mathrm{c}\right] \\
\text { pyrazinediium dibromide }\end{array}$ \\
\hline \multirow{6}{*}{ 光合成阻害 } & $\begin{array}{l}\text { DCMU } \\
\text { (diuron) }\end{array}$ & $\begin{array}{l}\text { 3-(3,4-dichlorophenyl)-1, 1- } \\
\text { dimethylurea }\end{array}$ \\
\hline & $\begin{array}{l}\text { linuron } \\
\text { (afaron) }\end{array}$ & $\begin{array}{l}\text { 3-( } 3,4 \text {-dichlorophenyl })-1-\text { methoxy- } \\
1 \text {-methylurea }\end{array}$ \\
\hline & simetryne & $\begin{array}{l}\text { 2-methylthio-4,6-bis-ethyla mino-s- } \\
\text { triazine }\end{array}$ \\
\hline & prometryne & $\begin{array}{l}2,4 \text {-bis(isopropylamino)- } 6 \text { - } \\
\text { methylthio- } s \text {-triazine }\end{array}$ \\
\hline & $\begin{array}{l}\text { DCPA } \\
\text { (propanil) }\end{array}$ & 3,4-dichloropropionanilide \\
\hline & $\begin{array}{l}\text { DCPA } \\
\text { 類縁化合物 }\end{array}$ & $\begin{array}{l}\text { propion anilide } \\
\text { 4-chloropropionanilide } \\
3,4 \text {-dichloroacetanilide }\end{array}$ \\
\hline
\end{tabular}

DCPA の類縁化合物の propionanilide, 4-chloropropionanilide および 3,4-dichloroacetanilide 核当す る aniline と脂肪酸より常法で合成し再結精製したもの を用いた。Paraquat と diquat は水に溶解し $10^{-2} \mathrm{Mol}$ の濃度に，その他はエタノールに溶解し $10^{-3} \mathrm{Mol}$ の濃 度に調製し, 褐色試薬瓶に入れ, 暗所に保存 したものを stock solution とした。

\section{（2）クロレラ增殖阻害率測定方法}

斜面および液体通気培養によって増殖した Chlorella elliposidea Gerneck C-27 50 $\mathrm{m} l$ 容扁平培養フラスコに一定量をとり, 培 養液で一定濃度に希釈した供試化合物を加 え, 24 時間, 螢光灯 $6,000 \mathrm{lux}$ 照射下 で約 $3 \%$ の $\mathrm{CO}_{2}$ を混合した空気を通じなが ら培養し, 増殖量を光電分光光度計 (波長 $574 \mathrm{~nm}$ ) で測定した。

増殖阻害率 $=$

$(1$ 一除草剤処理区の吸光度一培盖開始洔の吸光度 $) \times 100$
なお，実験方法の詳細は別報 ${ }^{1)}$ のとおりである。

\section{(3) クロレラ $\mathrm{O}_{2}$ 発生量の測定方法}

クロレラ細胞の䀣濁液を用い, 炭酸緩衝液中で, $25^{\circ} \mathrm{C}$, 約 6,000 lux の光の照射のもとで， $\mathrm{O}_{2}$ 発生量に及ぼす 薬剤の影響を $Z \mathrm{WEIG}^{12)}$ らの方法により，ワールブルグ 検圧計で測定した。

\section{（4）トマトに対する連合作用}

ポット植えのトマト（草丈 $12 \sim 15 \mathrm{~cm}$ ) に市販の paraquat 液剂, DCMU 水和剂を所定の濃度に希釈し, 茎葉に $5 \mathrm{cc}$ ずつ加圧散布して, 連合作用の有無を散布 7 日後に検討した。実験は 2 連制で行われた。

\section{（5）水稲に対する連合作用}

径 $9 \mathrm{~cm}$, 高さ $12 \mathrm{~cm}$ のポットに播種・育成した水稲 (3. $5 \mathrm{~L}$ 期，草丈 $12 \sim 15 \mathrm{~cm}$ ) に市販の DCPA 乳剤およ び DCPA 類縁化合物を所定の濃度に希釈して, $10 \mathrm{cc}$ ずつ茎葉に加圧散布し, 散布 5 日後に調查した。DCPA 類縁化合物は下記の処方で乳剂を調製した。

$$
\begin{aligned}
& \text { 類縁化合物：35\% キシロール : } 30 \% \\
& \text { イソホロン: } 25 \% \text { ソルポール } 80 \mathrm{~B}: 10 \%
\end{aligned}
$$

\section{3. 結果および考察}

\section{（1）独立連合作用}

Paraquat および DCMU の薬量－クロレラ増殖阻害 度回帰值線は第 1 図に示すとおりであり，回帰方程式は paraquat: $Y=2.00 X+14.94$, また DCMU $: Y=1.34$ $X+13.78$ ( $X$ : 薬量 $\mathrm{Mol}$ の対数, $Y$ : 増殖阻害度 $\%$ のプロビット) であった。

この両剤の混合比率を変えて混合した場合のクロレラ 増殖阻害度は第 2 図に示すとおり，図の中央で最も低く なっている。両端の単用の場合の処理濃度は, 上記回帰 直線から求めた $\mathrm{IP}_{50}$ 值であるので, 中央の混合比率は paraquat: DCMU $=10^{-5}: 2.8 \times 10^{-7}(\mathrm{Mol})$ となり， 


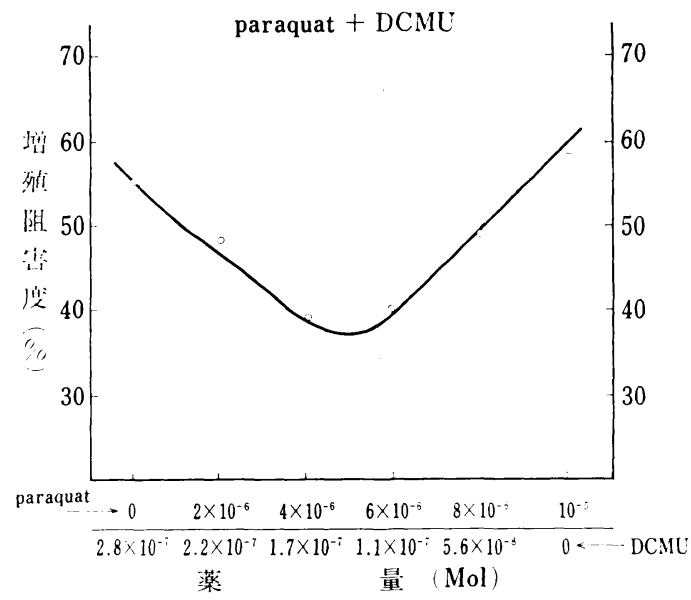

第 2 図 混合比率の阻害度に及ぼす影響

この比率での混合で最も拮抗作用が強く現われることが 期待される。また, paraquat と DCPA との混合の場合 も，第3図に示すと抢り，paraquat とDCMU との混 合々同様の結果を得た。第 1 図の paraquat $+\mathrm{DCMU} の$ 回帰直線はこの比率での混合によるもので, 回帰方程式 は $Y=2.27 X+16.57$ である。各回帰直線は $\chi^{2}$ の確 率がいずれも $70 \%$ 以上であり，良好であった。

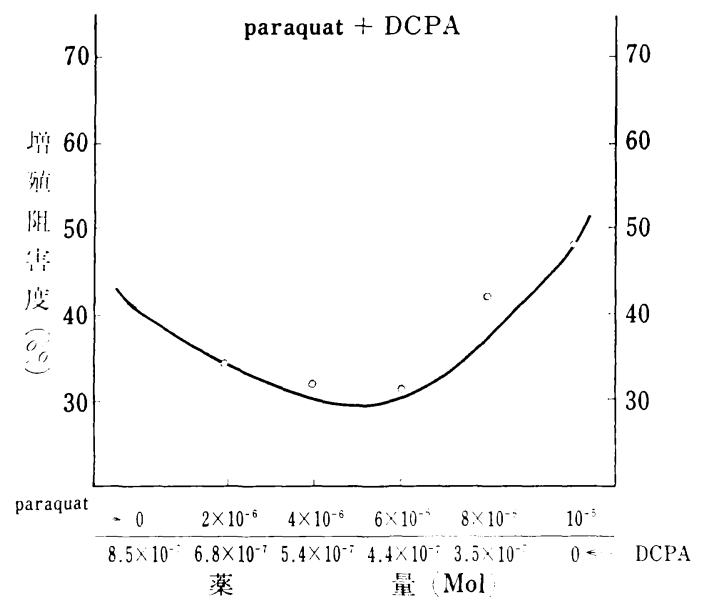

第 3 圀混合比率の阻害度に及ぼす影響

Paraquat ŁDCMU はその作用点が異なり，前者は 光化学系Iの電子伝達系においてフェレドキシンの作用 部位において電子を受けとり，フリーラジカルを生成 し，これが酸素を還元し過酸化水素を発生し，植物を枯 死させると考えられている6)。一方 DCMU は光化学系 IIに扔いて，クロロフィルの活性部位と結合し，その働 きを阻害するといわれている9”。したがって，この両剤
の混合による連合作用は独立連合作用であると推定され る。供試植物の両薬剤に対する感受性に相関関倸がない と仮定すると，交互作用のない場合の混合処理による効 果は, $P=P_{1}+P_{2}\left(1-P_{1}\right)\left(P_{1}, P_{2}\right.$ : 両薬剂単用での効 果, $P$ : 混合効果) で表わされる(0)。この仮定に基づ き, 第 1 図の paraquat $+\mathrm{DCMU}$ 混合の回帰直線を見 ると上記の式で算出される期待值を下まわっており，例 えば, $75 \%$ の阻害度が期待される混合処理での実験結 果は $58 \%$ の阻害であり, paraquat とDCMU の混合 はクロレラの増殖阻害にかんして拮抗的に作用すると判 断される。また混合処理の回帰直線の勾配は，第 1 図に 示すとおり，paraquat 単用の勾配と殆んど一致してお り，混合処理した場合のクロレラ増殖阻害の効果は主と して paraquat の効果の現れであって，DCMU の作用 が消失しているものと想定される。

クロレラ細胞の懸濁液を用い，その $\mathrm{O}_{2}$ 発生量に及ぼ す影響を測定した結果を第 4 図に示す。この処理濃度は 単用区は $I_{50}$ であり，混合区はそれぞれを加え合わせた

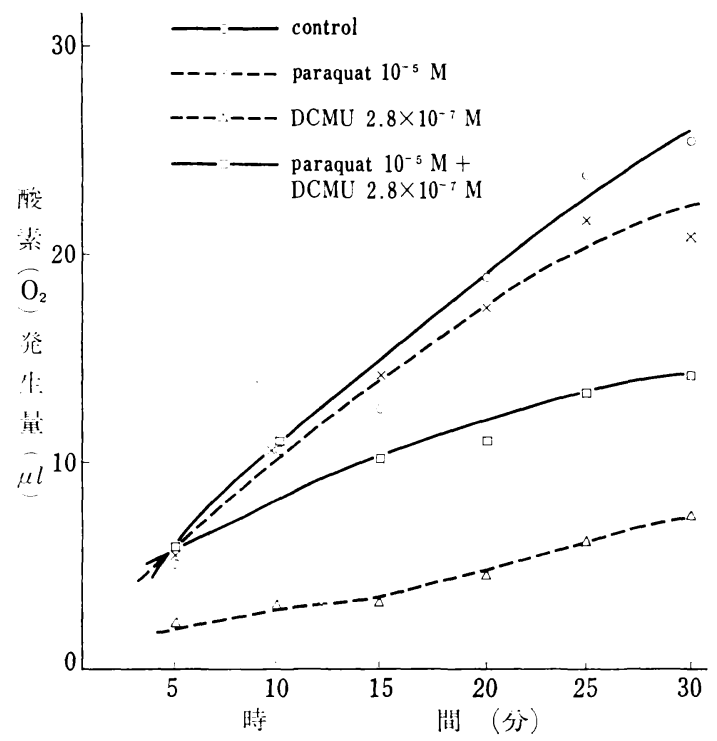

第 4 図クロレラの酸素発生に及ぼす影響

濃度である。DCMU はクロレラの $\mathrm{O}_{2}$ 発生を大きく阻 害しているのに対し， paraquat は無処理をやや下まわ る程度であった。これは DCMU は光化学系II 自体を 阻害するのに対し， paraquat は系川における水の還元 を直接的には阻害しないためと判断される。両薬剤の混 合区では単用区のほぼ中間の $\mathrm{O}_{2}$ 発生量が認められた。 これは, DCMU 単用で $\mathrm{O}_{2}$ 発生が大きく阻害されてい るのを，paraquat が加えられることによって DCMU 
の阻害力が弱められて, $\mathrm{O}_{2}$ 発生量が増加したと判断さ れる。

Dipyridinium 系除草凨と尿素系あるいは酸アマイド 系などのヒル反応阻害力を持つ除草剤を混用すると拮抗 作用を示すことについては，すでにいくつかの報告がな されている。 $\mathrm{MEES}^{8)}$ は diquat と CMU との混用が豆 の葉の薬斑発現に拮抗的であると報告している。松中 ${ }^{7}$ は paraquat とDCPA との混用がイネに対し拮抗的で あると報告している。これら拮抗作用の機作としては， ヒル反応阻害剂によって光合成が阻害され，dipyridinium 系除草剤の作用発現に必要な電子伝達がなされずフ リーラジカルの生成が抑えられるためと考えられてい る。しかし，筆者らのクロレラ増殖阻害試験および $\mathrm{O}_{2}$ 発生阻害試験の結果から, paraquat と DCMU との混 用はクロレラに対し捛抗的に作用し，これは paraquat が DCMU の作用を弱めるためと判断された。この拮 抗作用の機構については更に検討する必要があるが, $\mathrm{BAUR}^{3)}$ は paraquat がクロロプラスト構造に作用する と報告しており，物理的な作用により DCMU がクロ ロフイルの活性部位に結合しにくくなるという可能性も 考えられる。

第 2 表トマトに対する除草剤の連合作用 （処理濃度 $\times 10^{-7} \mathrm{Mol}$ )

\begin{tabular}{|c|c|c|}
\hline 草 & 処理 濃 度 & 殺草 程 度 \\
\hline paraquat 巣 用 & 3.1 & +++ \\
\hline DCMU 単 用 & 3.4 & $++t+$ \\
\hline paraquat $+D C M U$ & $3.1+3.4$ & $++t^{*}$ \\
\hline paraquat 单 用 & 2.1 & +++ \\
\hline DCMU 単 用 & 2.3 & $+t+t$ \\
\hline paraquat + DCMU & $2.1+2.3$ & ++ \\
\hline paraquat 単 用 & 1.4 & ++ \\
\hline DCMU 筫 用 & 1.5 & +++ \\
\hline paraquat + DCMU & $1.4+1.5$ & + \\
\hline
\end{tabular}

注 1) 殺草程度は 5 段階で肉眼観察した。+：微, $++:$ 小, +++ ： 吸, ++++ : 大, +++++ 極大

2)*外兄症状はパラコートのそれである。
一方，トマトに対して，市販の paraquat 液剤と DCMU 水和剤を茎葉散布した結果，第 2 表に示すと おり,クロレラの場合と同様に拮抗作用が出現した。 CoLBY $^{5)}$ は paraquat と CMMP との混用は, トマト には拮抗的に作用するが，メヒシバに対しては相乗的に 作用すると報告している。クロレラと高等植物とでは薬 剤に対しての反応性の相違（酵素采やライフサイクルの 相違にもとづく) があるから，クロレラで得られた結果 を高等植物に，一概に敷衍することはできない上考えら れる。

\section{(2) 類似連合作用}

Dipyridinium系, triazine系, 尿素系の各 2 薬剤の 薬量一クロレラ増殖阻害度回帰直線は, 各系毎にほぼ平 行になり，回帰直線方程式および $\mathrm{IP}_{50}$ 值は下記のとお りであった。なお，Xは薬量 Mol 濃度の対数, $Y$ はプ ロビット単位の阻害度である。

Dipyridinium 系

$$
\begin{array}{lll}
\text { paraquat }: Y=2.00 X+14.94 & \mathrm{IP}_{50} 1.1 \times 10^{-5} \mathrm{Mol} \\
\text { diquat }: Y=2.12 X+15.35 & \mathrm{IP}_{50} 1.3 \times 10^{-5} \mathrm{Mol}
\end{array}
$$

Triazine 采

simetryne : $Y=1.48 X+15.35 \quad \mathrm{IP}_{50} 1.0 \times 10^{-7} \mathrm{Mol}$ prometryne : $Y=1.46 X+14.46 I_{50} 3.3 \times 10^{-7} \mathrm{Mol}$ 尿素系

$$
\begin{array}{lll}
\text { DCMU } & : Y=1.34 X+13.78 & \text { IP }_{50} 2.8 \times 10^{-7} \mathrm{Mol} \\
\text { linuron } & : Y=1.38 X+13.65 & \text { IP }_{50} 5.3 \times 10^{-7} \mathrm{Mol}
\end{array}
$$

各回帰直線の直線性を $\chi^{2}$ 分布により検定したとこ ろ，いずれも $5 \%$ の危険率で直線性注否定できなかっ た。同じ系統のそれぞれ 2 薬剤の回帰直線方程式の勾配 は, どの系統の場合もほぼ一致しており, 同傾向の作用 を有することを示している。従って,これら 2 薬剤を組 み合わせた場合の連合作用は, 類似連合作用と推定され る。同系統間で，それぞれの両剤の混合比率を変えて混 合した場合のクロレラ増殖阻害度は第 5 図汇示すとおり
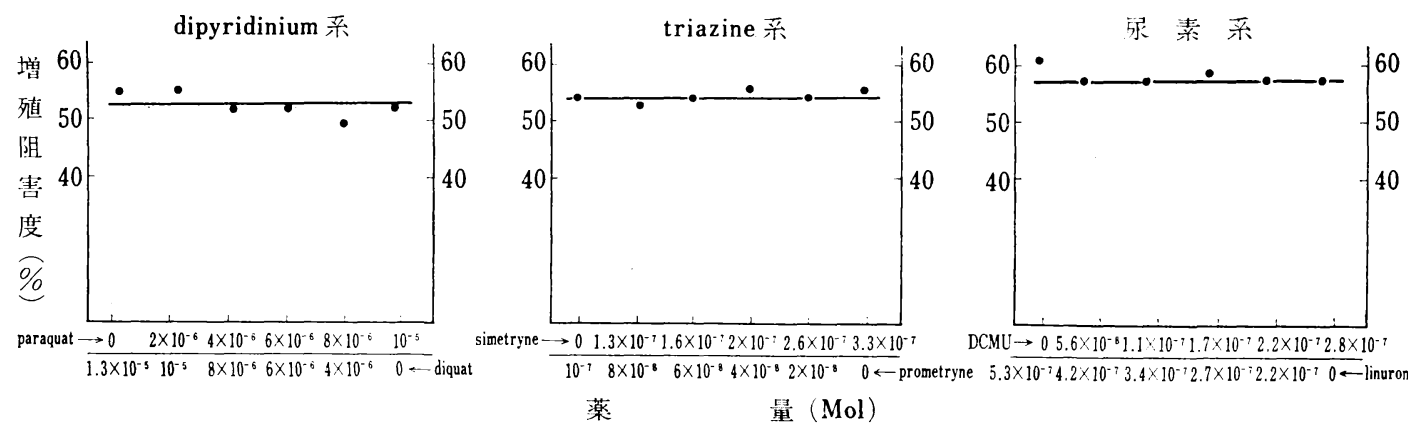

第 5 図各種除草剤の混合比率の阻害度に及ぼす影響 
で，いずれもほぼ50\% の阻害度で直線関係になってい る。両端の単用の場合の処理濃度は, それぞれの $\mathrm{IP}_{50}$ 值であるから，1薬剤が他薬剤に対して一定の割合でそ の作用を代行している。

すなわち，各両薬剤は同じ毒作用を呈し，等毒単位を 用いて，一方の薬剤はいかなる割合の他薬剤をも評価し 置き換えることができる。このことは，Burss ${ }^{4)}$ の類似 連合作用の概念をみたしているものと考えられる。ただ し, 同系統の薬剤でも, その化学構造のおずかな相違点 を特異的に解毒分解する機構を持つ生体内においては, 上記の結果とは別の傾向を示す可能性は十分想定され る。例えば，土壤微生物である Bacillus sphaerics は 尿素系除草剂のなかで， $\mathrm{N}-\mathrm{OCH}_{3}$ 基を持つ linuron を 高能率に分解するのに対し, それを持たない DCMU を全く分解しないことが知られている"1)。

\section{（3）協力作用}

DCPA の薬量ークロレラ増殖阻害度の回帰直線の回 帰方程式は, $Y=1.51 X+14.17$ ( $X$ : 薬量 $\mathrm{Mol}$ の対数, $Y:$ 増殖阻害度 \%のプロビット) で, その $\mathrm{IP}_{50}$ 值は $8.5 \times 10^{-7} \mathrm{Mol}$ である。次に, DCPA の $\mathrm{IP}_{50}$ 值と当 モル薬量で, 3 種の DCPA 類縁化合物を単独で処理し た場合，および DCPA とそれぞれの化合物を，やはり $\mathrm{DCPA}$ の $\mathrm{IP}_{50}$ 值と当モルずつ混用した場合のクロレラ 増殖阻害度を測定し，第 3 表の結果を得た。 3 種のう

第 3 表 DCPA とその類縁化合物のクロレラに 対する連合作用

(処理濃度は, 単用の場合 $8.5 \times 10^{-7} \mathrm{Mol}$, 混用の場 (合, 各々 $8.5 \times 10^{-7} \mathrm{Mol}$ ずつ加えた。阻害度は\%

\begin{tabular}{l|c}
\hline \multicolumn{1}{c|}{ 処 理 薬 } & クロレラ剂 \\
\hline DCPA 曾殖阻害度 \\
propionanilide 単用 & 48 \\
4-chloropropionanilide 単用 & 2 \\
3,4-dichloroacetanilide 単用 & 17 \\
DCPA+propionanilide & 6 \\
DCPA+4-chloropropionanilide & 51 \\
DCPA+3,4-dichloroacetanilide & 53 \\
\hline
\end{tabular}

ち，4-chloropropionanilide のみが単用でも多少の生 物活性をもったが，その他は殆んど活性を示さなかっ た。また，DCPA に，これら類縁化合物を加えても， DCPA の阻害度は殆んど変らなかった。従って，これ ら化合物はクロレラに対しては生物活性を殆んど有せ ずまた DCPA と混用しても協力作用を示さないもの と考えられる。

一方，同様の試験を，水稲に茥葉処理して行ない，第 4 表の結果を得た。類緣化合物単用の場合は, クロレラ の場合と同様, 生物活性を殆んど示さなかった。しか
第 4 表 DCPA そその類縁化合物の水稲に 対する連合作用

（処理濃度は $\times 10^{-5} \mathrm{Mol}$ )

\begin{tabular}{l|c|c}
\hline \multicolumn{1}{c|}{ 処理 } & 処理浀度 & 殺草程 度 \\
\hline DCPA 単用 & 1.6 & + \\
DCPA 単用 & 3.2 & + \\
propionanilide 単用 & 2.4 & - \\
propionanilide 単用 & 4.8 & + \\
4-chloropropionanilide 単用 & 1.9 & - \\
4-chloropropionanilide 単用 & 3.8 & + \\
3,4-dichloroacetanilide 単用 & 1.7 & - \\
3,4-dichloroacetanilide 単用 & 3.4 & + \\
DCPA+propionanilide & $0.8+1.2$ & + \\
DCPA+propionanilide & $1.6+2.4$ & +++ \\
DCPA+4-chloropropionanilide & $0.8+0.9$ & + \\
DCPA+4-chloropropionanilide & $1.6+1.9$ & +++ \\
DCPA+3,4-dichloroacetanilide & $0.8+1.0$ & + \\
DCPA+3,4-dichloroacetanilide & $1.6+1.7$ & +++++ \\
\hline DCPA+MTMC & $1.6+0.91$ & +++++ \\
\hline
\end{tabular}

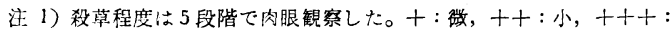
中, $++++:$ 大, $+++++:$ 極大

2) MTMC はカーパメート系殺蛕の $m$-tolyl methlcarbamate

し, DCPA と混用すると, 3 種とも DCPA 単用の場 合よりも殺草効果は増幅しており, 明らかに協力作用が 認められた。これら類縁化合物は，イネ体内で DCPA と同様に加水分解されることは，すでに明らかにされて おり ${ }^{2)}$ ，DCPA と同時にイネ体内にとりこまれた場合 に，DCPA と拮抗するのではないかと推測される。こ のことは DCPA 加水分解の酵素反応を動力学的に検討 することによって明確にされるべきである。またクロレ ラの場合に協力作用を示さなかったのは，クロレラが DCPA 加水分解酵素をもたないことに一因があろう。

\section{4. 摘要}

光合成阻害剂について, Burss の連合作用の 3 作用 型，すなわち独立連合作用，類似連合作用，協力作用を 検討した。Paraquat とDCMU は独立連合作用を示 し，相互に拮抗した。Dipyridinium 系の paraquat と diquat, triazine 系の simetryne と prometryne, 尿 素系の DCMU と linuron は，それぞれ類似連合作用 を示し，1薬剤が他薬剤に対して一定の割合でその作用 を代行することができた。DCPA とその 3 種の類縁化 合物は，クロレラに対しては協力作用を示さなかった が，水稲に対しては協力作用を出現させた。

なお，本研究に使用した除草剤のサンプルをご提供い ただいた関係会社各位に深謝の意を表する。

\section{引 用 文 献}

1) 足立明朗・浜田虚二：クロレラ利用に上る除草剤検定について。 雑草研究 11, 54 (1971).

2）足立明朗・利根川和江・上島俗治 : 3, 4-Dichloropropionanilide 
の選択殺草作用汇関する研究（第 2 報）イネ DCPA 分観醭素沉 ついて. 農薬生産技術 15, 11 (1966).

3) Baur, J.R., R.W. Bovey, P.S. Baur, and Zenab ElSEIFY: Effects of paraquat on the ultrastructure of mesoquit mesophyll cells. Weed Res. 9, 81 (1969).

4) BLIss, C. I.: Ann. Appl. Biol. 26, 585 (1939).（酒井清六 : 殺虫剂の連合作用汇関する昆虫毒物学的研究 (1960) より).

5) Colby, S. R., T. Wojtaszek, and G.F. WARREN: Synergistic and antagonistic combinations for broadening herbicidal selectivity. Weeds 13, 87 (1965).

6) Funderburk, H.H. Jr., and J.M. Lawrence: Mode of action and metabolism of diquat and paraquat. Weeds 12, 259 (1964).

7) Matsunaka, S.: Activation and inactivation of herbicides by higher plants. Residue Reviews 25, 45 (1969).
8) MEES, G.C.: Experiments on the herbicidal action of 1, 1'-ethylene-2, 2'-dipyridylium dibromide. Ann. Appl Biol. 48, 601 (1960).

9) Moreland, D. E., and K.L. Hill: Inhibition of photochemical activity of isolated chloroplasts by acylanilides. Weeds 11, 55 (1963).

10）酒并清六：殺虫版検定の予测性. 農楽生産技術 2, 23 (1960)

11) WALLNöFER, P.: The decomposition of urea herbicides by Bacillus sphaericus, isolated from soil. Weed Res. 9, 333 (1969).

12) ZWEIG, G.: The effect of photosynthesis inhibitors on oxygen evolution and fluorescence of illuminated Chlorella. Biochem. Biophys. Acta 66, 196 (1963).

(1971 年 5 月 10 日受付)

\section{Joint Action of Photosynthesis Inhibiting Herbicides \\ Meiro Adachi and Kenji Hamada \\ Zenkoren Agricultural Technical Center, Hiratsuka, Kanagawa}

\section{Summary}

Joint action of herbicides was studied on combination of several photosynthesis-inhibitors.

Combination of paraquat with DCMU was antagonistic on phytotoxicities to Chlorella elipsoidea and tomato plants. It was assumed that paraquat decreased the activity of DCMU on light system II .

Similar joint actions were typically observed on combinations of related compounds, i. e. paraquat with diquat, simetryne with prometryne, and DCMU with linuron.

Combinations of propanil with its related compounds were synergistic on rice plants, but not Chlorella elipsoidea.

\section{除草剤が土壤環境に与える影響に関する研究}

\section{一硝 化 作 用 について一}

\section{農林省農事試験場 野口勝可・中沢秋雄*}

\section{1. 緒言}

近年，除草作業の省力化といら観点から，除草剤の使 用はますます多くなりつつある。しかるに，わが国で は，これまで除草剤の作用については，作物に対する影 響と除草効果の面の検討に多くかたより，それが土潩環 境にどのような影響を与えるかについては，PCP につ いての若干の報告1をを除いて、あまり検討がなされてい な以。一方, 薬剤が土壤環境に与える影響は多様である ことが報告 2)されており，その使用にあたっては，直接

\footnotetext{
* 現在 農林省九州農業試験場作物第 2 部
}

的な効果ばかりでなく，土袞環境に与える影響などを総 合的な面からとらえておく必要がある。

本研究は，除草剤が土㙵環境に与える影響のうち，農 業上重要な土塨の硝化作用に与える影響について検討し たものである。

\section{2. 試験材料および方法}

農林省農事試験場畑作部（埼玉県北本町）围場の火山 灰土壤を採取, 風乾後笠別した径 $2 \sim 4 \mathrm{~mm}$ の土壤団粒 を使用した。

除草剂は，畑作で一般に使われているもので，種々の 